\title{
Capillary electrophoresis applied to DNA: determining and harnessing sequence and structure to advance bioanalyses (2009-2014)
}

\author{
Brandon C. Durney ${ }^{1} \cdot$ Cassandra L. Crihfield $^{1} \cdot$ Lisa A. Holland ${ }^{1}$
}

Received: 12 February 2015 /Revised: 9 April 2015 / Accepted: 13 April 2015 /Published online: 3 May 2015

(C) The Author(s) 2015. This article is published with open access at Springerlink.com

\begin{abstract}
This review of capillary electrophoresis methods for DNA analyses covers critical advances from 2009 to 2014, referencing 184 citations. Separation mechanisms based on free-zone capillary electrophoresis, Ogston sieving, and reptation are described. Two prevalent gel matrices for gelfacilitated sieving, which are linear polyacrylamide and polydimethylacrylamide, are compared in terms of performance, cost, viscosity, and passivation of electroosmotic flow. The role of capillary electrophoresis in the discovery, design, and characterization of DNA aptamers for molecular recognition is discussed. Expanding and emerging techniques in the field are also highlighted.
\end{abstract}

Keywords DNA · DNA aptamer · Capillary gel electrophoresis $\cdot$ Sieving matrix

\section{Introduction}

Capillary electrophoresis separations are significant because they provide fast separations of limited sample volumes. Following reports of outstanding separation efficiencies of amines, amino acids, and peptides achieved using a $75-\mu \mathrm{m}$-inner-diameter glass capillary $[1,2]$, the technology was quickly adapted to DNA $[3,4]$. The rapid growth and sustained use of capillary electrophoresis for

Published in the topical collection Capillary Electrophoresis of Biomolecules with guest editor Lisa Holland.

Lisa A. Holland

Lisa.Holland@mail.wvu.edu

1 C. Eugene Bennett Department of Chemistry, West Virginia University, Morgantown, WV 26506, USA
DNA analyses is best illustrated by the number of annual journal publications, which is summarized in Fig. 1. Critical innovations reported early in the method development [5-10] dramatically increased the applicability to sequence and size DNA. Landmark applications include genome sequencing [11], forensic analysis of DNA with commercial systems [12,13], and lab-on-a-chip [14-17]. In addition to sizing DNA, capillary electrophoresis has played a pivotal role in the generation of DNA aptamers and the quantification of aptamer binding affinity.

As the technology matures, research-driven advances have been transformed into heavily utilized applications, generating a large user-base focused on applying the methodology. Perhaps the best indicator of progress in the field of capillary electrophoresis DNA separations is the translation of this technology into the teaching laboratory $[18,19]$. Capillary electrophoresis separations of DNA have been integrated in teaching exercises in genomic identification of food with a commercial chip [18]. Despite the maturity of this technology innovative research and new applications are reported. The goal of this review is to summarize developments in the use of capillary electrophoresis for DNA analyses. This paper includes capillary electrophoresis techniques reported from 2009 to 2014 that address critical barriers. The review begins with a brief discourse on the mechanisms relevant to DNA separations.

\section{Separation}

Capillary electrophoresis is a high-throughput separation method commonly employed for DNA analysis owing to rapid analysis times and small sample volumes. Various modes of capillary electrophoresis, which are summarized in Table 1, are used depending upon the application. Free- 
Fig. 1 Number of publications on capillary electrophoresis separations of DNA in the

SciFinder ${ }^{\mathbb{B}}$ database

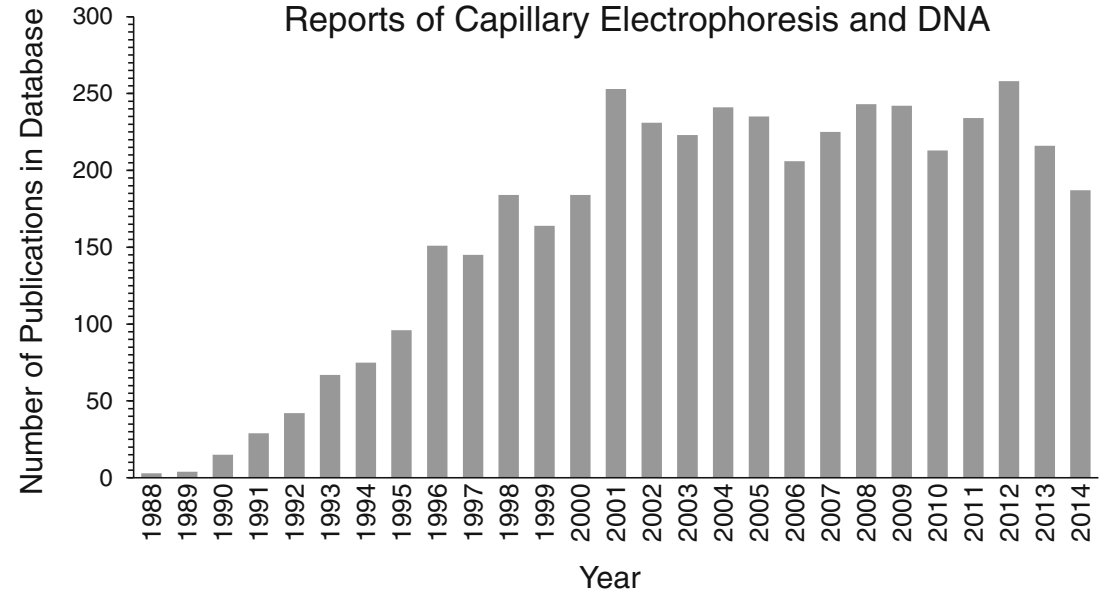

zone and gel-facilitated sieving are the most commonly reported modes for DNA analyses. Unfortunately, freezone capillary electrophoresis methods for DNA separations are limited because of the similar charge-to-size ratio of fragments of different length. To circumvent this problem gels are incorporated in capillary electrophoresis separations to sieve DNA fragments on the basis of size.

Table 1 Capillary/microchip electrophoresis mechanisms

\section{Free solution / electrophoretic mobility}

Mechanism:

Electrophoretic mobility (i.e. charge-to-size ratio of fragment)

Attributes

+ Simple to implement

- Poor separation of similar DNA charge-to-size ratio

Application:

Affinity studies with DNA aptamer

Ogston sieving: sieving through a gel with pores $\geq$ DNA Radius of Gyration

\section{Mechanism:}

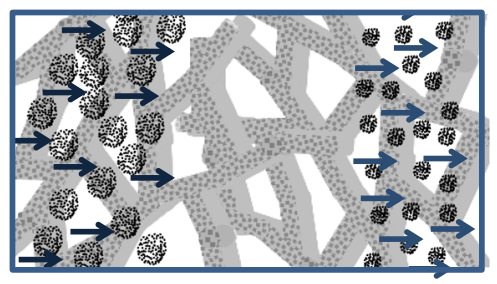

Electromigration through pores; size determines probability of impeded motion

Attributes

+ Relationship between length and migration linear

+ Sizing \pm 1 base

- Limited to fragments < 1000 nucleotides

Application:

Sizing for species identification, or disease markers

Reptation: sieving through a gel with pores $\leq$ DNA Radius of Gyration

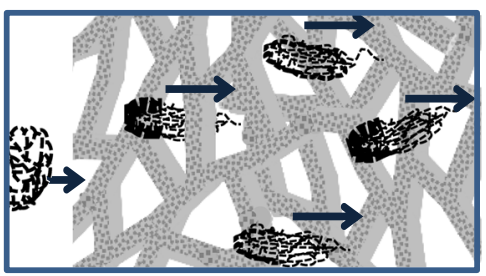

\section{Mechanism:}

Electromigration of DNA through pores requires deformation; nonlinear correlation between size and time to traverse gel

\section{Attributes}

+ Suited for fragments $>1000$ nucleotides

- Size precision poor

Application:

Coarse sizing/fingerprinting, comet assays 


\section{Gel-facilitated sieving}

Gel-facilitated sieving is one of the most commonly used methods for sequencing DNA in parallel analyses and sizing. Electroosmotic flow is suppressed by coating the surface of the capillary, and then the capillary is filled with sieving gel. Ogston sieving and reptation are the mechanisms of DNA transport through the gel. In Ogston sieving, shown in Table 1, DNA behaves as an incompressible sphere. The separation, which occurs with suppressed electroosmotic flow under reversed polarity, is based on the ability of DNA to pass unobstructed through the pores formed by the gel matrix. Smaller fragments of DNA migrate faster than longer fragments, and a linear relationship is observed between fragment size and migration time. Both sequencing and sizing are conducted within the Ogston regime. Reptation, which is depicted in Table 1, occurs when a DNA molecule is too large to pass freely through the pores of the gel and must deform or unfold to fit through the matrix. With this mode of sieving, the relationship between migration time and DNA fragment size is non-linear and peak resolution is worse, which makes sizing difficult. The fragment size at which the separation transitions from Ogston sieving to reptation can be approximated with a DNA size ladder and determined experimentally. A variety of matrices for DNA separations have been reviewed [20-26].

\section{Characteristics of DNA sieving gels}

Prevalent matrices used for sequencing or sizing from 2009 to 2014 are summarized in Table 2. The factors that determine which separation matrix is utilized for a specific application are included in the table. The separation performance, which is the most critical figure of merit of a sieving gel, is measured by the chromatographic resolution and the upper size limit for Ogston sieving. Chromatographic peak resolution (Rs), is defined as $\operatorname{Rs}=(\Delta t) / W_{\text {ave, }}$ where $\Delta t$ is the difference in migration times of two adjacent peaks and $W_{\text {ave }}$ is the average width of the peak at the base (estimated as $4 \sigma$ ) [27, 28]. Resolution is more often calculated using the width at half-height [29, 30], which for a Gaussian peak is $2.35 \sigma$, because it obviates practical issues associated with a noisy baseline or overlapping peaks [29]. For Gaussian peaks this calculation generates the same value as obtained using the width of the base [27]. Peak resolution can also be described in terms of the minimum number of nucleotides that are distinguishable for two DNA fragments. This is calculated by dividing the difference in the number of bases for the two adjacent peaks by the calculated chromatographic resolution. For simplicity, the resolution that can be expected for different sieving matrices is reported in Table 2 in terms of the size in bases by which fragments can reliably be distinguished from one another.
In addition to separation performance, the cost, viscosity, and coating capability of a gel must also be considered. A gel that is easily synthesized or readily available at a low cost is preferred. The viscosity of the gel matrix is also critical because high pressure systems are required to introduce and remove viscous gels from capillaries. Such high pressures are incompatible with microfluidics. Coating the capillary or channel surface is necessary to suppress the electroosmotic flow. The coating must be stable and the effect on electroosmotic flow reproducible.

Linear polyacrylamide is used in capillary gel electrophoresis techniques owing to outstanding performance and low cost. The disadvantages of linear polyacrylamide are the high viscosity and inability to coat the surface of the capillary. Linear polyacrylamide is among the most viscous matrices used in DNA analysis; however, under a sheer force of $1.32 \mathrm{~s}^{-1}$, the viscosity of a $2 \%$ linear polyacrylamide gel drops to 27,000 cP [31]. A suppressed electroosmotic flow is required, and different strategies for surface modification have been reported [32-34].

Linear polyacrylamide matrices were used for various applications between 2009 and 2014. The synthesis and optimization of two linear polyacrylamide matrices for the capillary electrophoresis separation of DNA fragments with less than 70 bases was reported and applied to size PCR markers for wild-type and mutant gastric cancer tissues with a resolution below five bases [35]. A $5 \%$ linear polyacrylamide matrix was used in an integrated microfluidic lab-on-a-chip platform for DNA extraction, amplification, separation, and detection from a crude biological sample, and a full profile of short tandem repeats (STRs) was obtained for a standard DNA template in a 40-min analysis time [34]. Other microfluidic platforms utilizing linear polyacrylamide were employed for the analysis of E. coli [36-38], Staphylococcus aureus [37, 39], Salmonella typhimurium [37], human respiratory viruses [40], Alu insertions used for gender and ethnicity determination [41, 42], p53 gene mutations [43], and EndoV/DNA ligase mutations [44].

Polydimethylacrylamide matrices overcome the two major limitations of linear polyacrylamide sieving gels: viscosity and coating ability. The most prevalently used polydimethylacrylamide matrix is performance optimized polymer 4 (POP-4 $\left.{ }^{\mathrm{TM}}\right)$, which contains $4 \%$ polymer with $5 \%$ 2-pyrrolidinone and $8 \mathrm{M}$ urea [45]. Single-base resolution of DNA fragments up to 250 bases and two-base resolution up to 350 bases have been demonstrated within a 31-min separation for forensic DNA applications [46]. Other POPTM matrices containing higher percentage polymer concentrations have been optimized for sequencing applications. Matrices of $6.5 \%$ polydimethylacrylamide have a viscosity between 75 and $1200 \mathrm{cP}$ depending on whether the low or high molecular weight polymer is used in the synthesis reaction [47]. The POP-7 ${ }^{\mathrm{TM}}$ formulation has a viscosity of only $395 \mathrm{cP}$ [48]. 
Table 2 Gels used for DNA sequencing and sizing applications

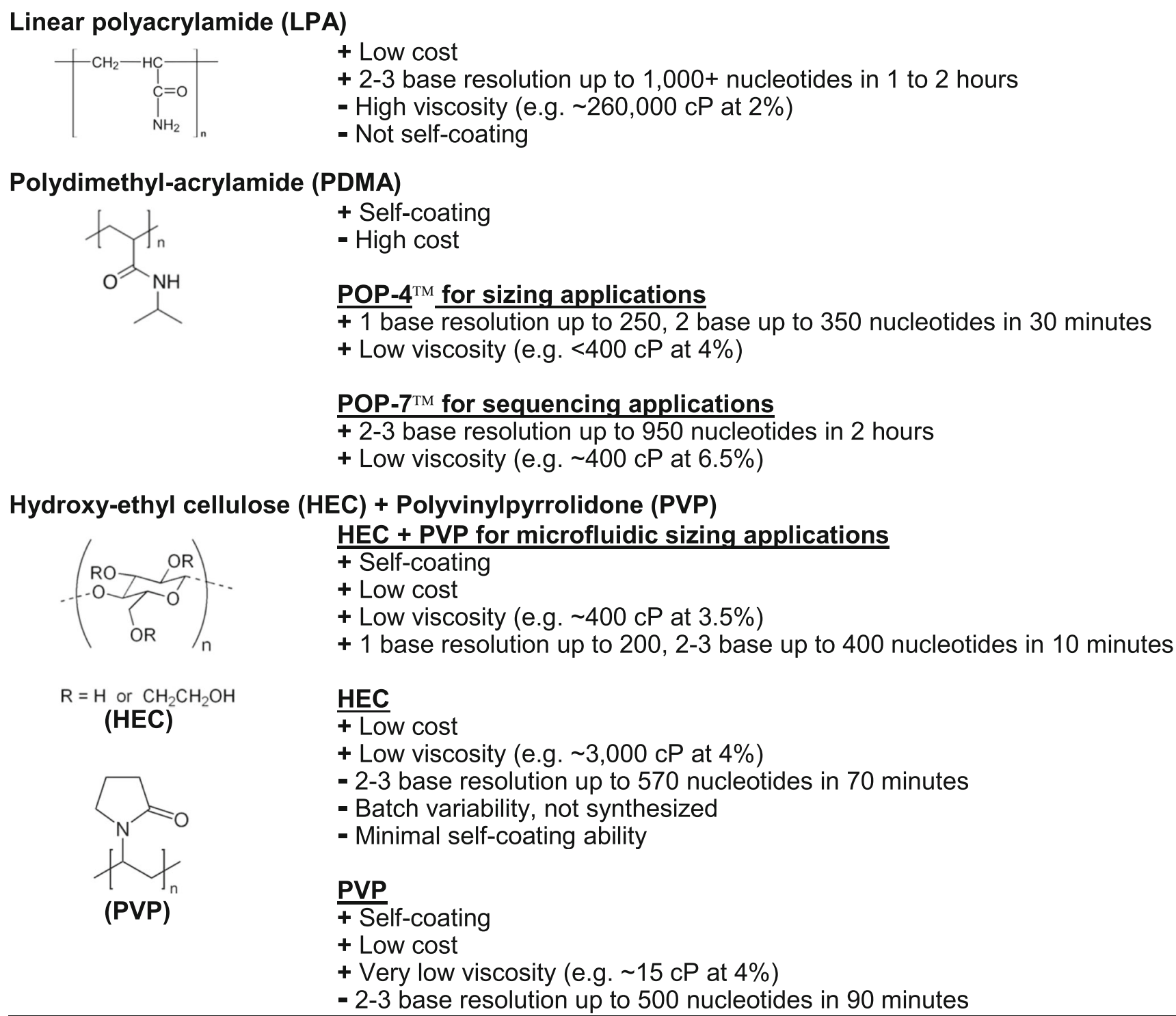

The low viscosity is an advantage of polydimethylacrylamide. Unlike linear polyacrylamide, polydimethylacrylamide can coat the surface, so other coating materials or modifications are not required. The advantages of using a polydimethylacrylamide sieving matrix come at a cost, as it is the most expensive matrix available with POP-4TM (cat. \# 402838 or \# 4363752) available at a cost of approximately US\$60 per $\mathrm{mL}$ [49]. It is also expensive to synthesize a polydimethylacrylamide matrix using the dimethylacrylamide monomer, but has been shown to yield comparable separation performance to commercially available matrices of polydimethylacrylamide in capillary electrophoresis [50] and linear polyacrylamide in a microfluidics platform [51]. The material is heavily used in forensics applications. New integrated microfluidics have been applied to methylated DNA using polydimethylacrylamide sieving gel to identify whether a forensic sample source was tissue [52], body fluid [53], or semen [54] and has been utilized to analyze seminal stains as old as 56 years [55], as well as analyzing polymorphisms of STRs [56].

Matrices composed of polydimethylacrylamide are also employed for a variety of applications outside of forensics. Sizing DNA with new matrices [57] and microfluidic platforms developed for STR analysis [58, 59] are often compared to bench-top analyses achieved using polydimethylacrylamide matrices. Applications of polydimethylacrylamide matrices outside of forensics include multi-locus variable number repeat analysis to genotype several bacteria including Shigella spp. [60], Streptococcus agalactiae [61], Staphylococcus aureus 
[62], Clostridium difficile [63], Listeria monocytogenes [64], Legionella pneumophila [65], Pseudomonas aeruginosa [66], and Francisella noatunensis [67], and study the association of specific point mutations with susceptibility to particular antimicrobial agents [68]. These matrices also have merit in the agricultural field having aided in methods for sizing biomarkers for the identification of seven pathogenic species in bovine milk [69]. They have also been used in distinguishing genetically modified cotton and soybean [70], and single strand conformational analysis for the identification of seven infectious diseasecausing pathogens [71].

Hydroxyethylcellulose, a polysaccharide-based gel derived from cellulose, is a low cost and low viscosity matrix; however, with this matrix the electroosmostic flow is not eliminated but is only suppressed by $20 \%$ [72]. A drawback to utilizing hydroxyethylcellulose is polydispersity of the polymer chain because it is a naturally occurring polymer. Hydroxyethylcellulose matrices cost approximately US $\$ 0.14$ per gram [73] with low viscosities at dilute concentrations. An early application of hydroxyethylcellulose for DNA separations yielded two-base resolution at an upper size limit of 570 bases using a $2 \%$ matrix composed of polymer with a molecular weight range of 90-105 kDa that had been purified using an ion-exchange resin [74]. The viscosity of hydroxyethylcellulose matrices can be adjusted so that it can be suited for separating DNA of different size ranges by varying the percentage of low and high molecular weight hydroxyethylcellulose in the preparation [75]. A lower molecular weight, 90-kDa hydroxyethylcellulose matrix was used for the identification of genetically modified maize with DNA markers less than 200 bases [76]. A blended hydroxyethylcellulose matrix consisting of $0.21 \% 27-\mathrm{kDa}$ and $0.07 \%$ 1-MDa hydroxyethylcellulose with $0.12 \% 7$ MDa linear polyacrylamide was used for the separation of DNA fragments ranging from 200 to 40,000 bases in 2 min in a glass microfluidic coated with polyhydroxyethylacrylamide [77]. The poor surface passivation by hydroxyethylcellulose can be overcome by blending other effective surface coating agents such as polyethylene glycol [78], polyvinyl alcohol [79], and polydimethylacrylamide [79].

Polyvinylpyrrolidone is a sieving matrix with mediocre separation performance, but excellent surface coating properties, low cost [80], and low viscosity, which can range from only 3 to $27 \mathrm{cP}$ [81]. Polyvinylpyrrolidone matrices have been reported to demonstrate the feasibility of using short capillaries [82], performing portable methods [83], and improving detection through base stacking and field gradients [84]. Although this matrix is not widely used, a newly developed blended sieving matrix comprised of $20 \%$ polyvinylpyrrolidone and $80 \%$ hydroxyethylcellulose [57] harnesses the complementary properties of each material. Polyvinylpyrrolidone is an excellent coating material, and hydroxyethylcellulose provides better separation performance. The viscosity of the mixture is lower than a matrix containing only hydroxyethylcellulose and has been used for more than 90 consecutive capillary electrophoresis runs without deterioration in separation performance [85]. The matrix is mainly used in microfluidic platforms for DNA sizing for human identification STR analysis because it provides single-base resolution up to 200 bases and two- to three-base resolution up to 400 bases in a 15-min separation [58].

\section{Pivotal applications of capillary gel electrophoresis for DNA sieving}

\section{Beyond de novo genome sequencing}

Next-generation sequencing strategies are now commercialized as cheaper and faster alternatives based on highly multiplexed analysis of short reads [86]. However, Sanger sequencing via capillary gel electrophoresis is still commonly used to correct for errors in assembling the sequence data, for example in long repeats of DNA polymers. Thus, capillary gel electrophoresis is reported as an analytical technique used to assist in genome sequencing with next-generation sequencing technology. Capillary gel electrophoresis is used to improve quality control in next-generation sequencing [87], or to quantify the DNA library [88]. Droplet microfluidics was used in conjunction with capillary gel electrophoresis to ensure that a suitable amount of DNA is generated by PCR without a bias in size distribution [89].

\section{End-labeled free-solution electrophoresis}

End-labeled free-solution electrophoresis relies upon free zone capillary electrophoresis to separate DNA fragments that are covalently attached to a large molecule, such as synthetic peptoids [90] or proteins [91], often referred to as drag-tags. DNA mobility decreases with the fragment size, so smaller fragments migrate slower than larger fragments due to a decrease in the charge-to-friction ratio. Decrease in the polydispersity of proteins used for drag-tags decreases variation in charge and size distribution, which extends the sequencing read length [91]. Increase in the charge on the drag-tag increases wall interactions, which increases band broadening [92, 93]. Micelle drag-tags have been utilized in commercial capillary electrophoresis instruments and microfluidics to improve the readout time by optimizing the electroosmotic counterflow [94]. Additional applications for drag-tag methods include hybridization assays with short single-strand DNA targets [95] for the detection of single nucleotide polymorphisms (SNPs) [96] or to assess the formation of primer dimers in multiplex PCR reactions [97]. 


\section{DNA sizing}

Beyond the use of capillary gel electrophoresis for DNA sequencing of the entire human genome, capillary gel electrophoresis continues to play a significant role in assigning STRs for human identification or detecting pathogen biomarkers. Repetitive sequences within the genome are harnessed to uniquely identify specific biomarkers for a number of applications relevant to pathogen detection, human disease, and especially human identification. DNA analyses are critical to forensic laboratories around the world. Human identification methods are based on the analysis of DNA sequences known as STRs, which contain two to five base repeats. For example, the STR Penta E has the recurring sequence AAAGA, and can vary among individuals from five to as many as 24 repeats of AAAGA. An individual will have two different sets of this repeat, one copy from each parent. Thirteen different STRs are used in the Federal Bureau of Investigation (FBI) combined DNA index system, also known as CODIS, for probability matching of a DNA sample to a specific individual. In a single forensic analysis a minimum of 16 markers are separated and sized. Four different fluorescent labels (e.g., FAM, JOE, TAMRA, ROX) are used to distinguish the STRs because some have similar length and overlap in separation space. Therefore, these overlapping lengths are resolved spectrally. The amplicons reflect the number of repeats at a specific locus, and the assignment of size is accomplished using a standard DNA ladder. These overlapping fragments are separated in the polydimethylacrylamide sieving gel matrix. The relationship between migration time and fragment size is linear. Sizing is used for genotyping through the identification of markers that have specific lengths and DNA sieving gels are critical to these separations.

\section{Chip-based forensics}

Microfluidic systems for forensic analyses continue to advance. Newer device designs generate results from buccal cells in under $3 \mathrm{~h}$ [98] or $4 \mathrm{~h}$ [58]. DNA from whole blood was processed using a device to integrate solid phase extraction with a $1.2 \mu \mathrm{L}$ PCR chamber [99]. A simple disposable chip fabricated in $10 \mathrm{~min}$ using a printer and polyester toner at a cost of US\$0.15 was reported [100]. A more sophisticated plastic microchip was reported for integrated sample extraction, PCR amplification, and DNA separation (Fig. 2A) and achieved single-base resolution of buccal samples with only a $7-\mathrm{cm}$ separation channel [101]. The plastic device is costeffective and was used over a 6-month period. In another report a microfluidic droplet generator, shown in Fig. 2B, was used for high-throughput isolation of single cells prior to integrated extraction, amplification, and sizing [102]. This approach of isolating single cells circumvents issues of

\section{a}
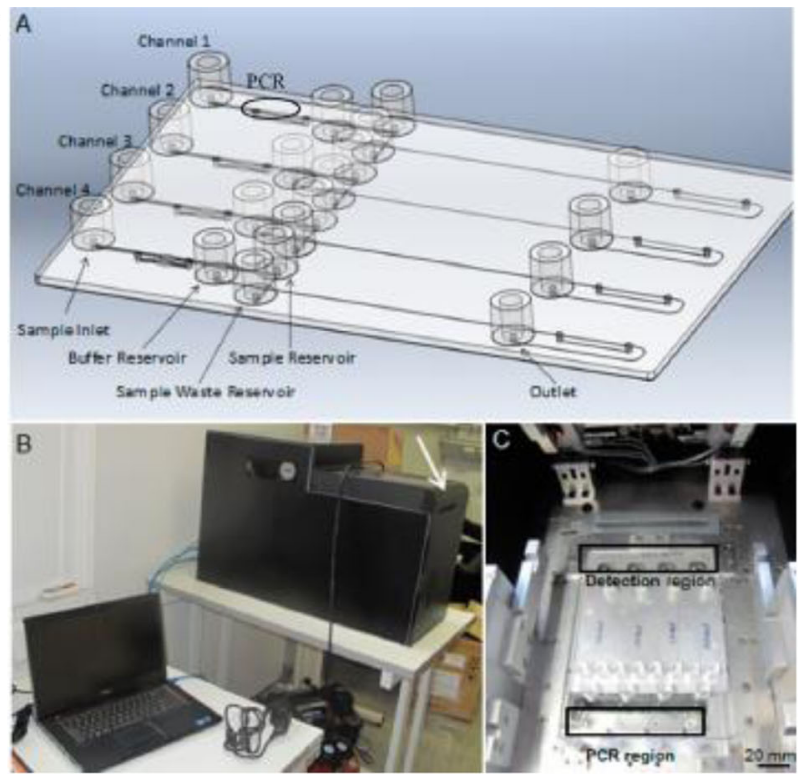

b
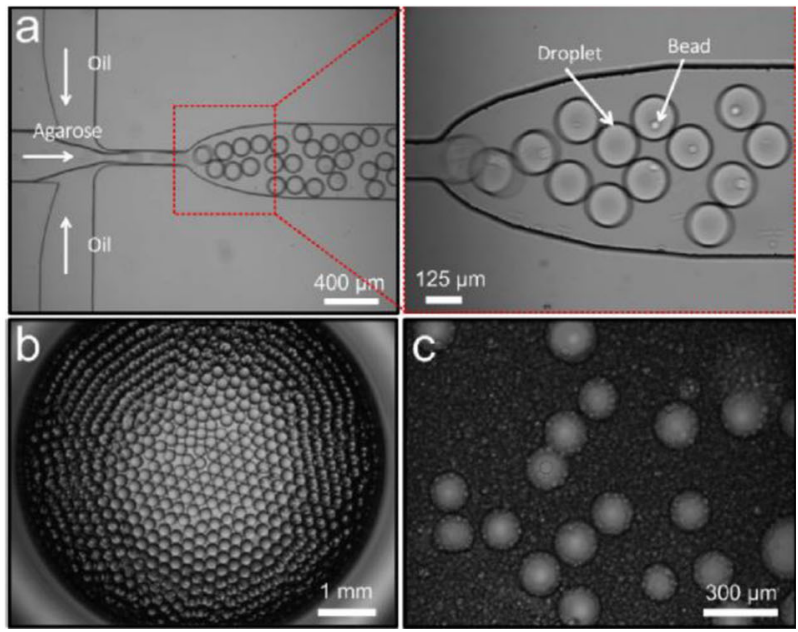

Fig. 2 Examples of microchip devices for integrated forensic analysis of DNA. a An integrated microchip fabricated for online sample extraction, PCR amplification, and separation. Reprinted with permission from Le Roux D, Root BE, Reedy CR, Hickey JA, Scott ON, Bienvenue JM, Landers JP, Chassagne L, de Mazancourt P (2014) DNA analysis using an integrated microchip for multiplex PCR amplification and electrophoresis for reference samples. Analytical Chemistry 86(16):8192-8199. Copyright 2014 American Chemical Society. b The process of separating cells into oil droplets using a microfluidic droplet generator for single-cell processing and analysis is depicted. Reprinted with permission from Geng T, Novak R, Mathies RA (2014) Single-cell forensic short tandem repeat typing within microfluidic droplets. Analytical Chemistry 86(1):703-712. Copyright 2014 American Chemical Society

analyzing and interpreting data obtained with DNA from multiple donors.

\section{Self-assembled gels}

Self-assembled gels with tunable selectivity are an alternative to POP-4TM gels. The phospholipids dimyristoyl-sn-glycero3-phosphocholine (DMPC) and 1,2-dihexanoyl-sn-glycero-3- 
phosphocholine (DHPC) spontaneously forms a thermally reversible nanogel for DNA sizing $[103,104]$. The nanogel adopts a bilayer nanodisk morphology at $19{ }^{\circ} \mathrm{C}$ which corresponds to a low loading viscosity of $50 \mathrm{cP}$ for a $20 \%$ solution [105]. When the temperature is increased to $30{ }^{\circ} \mathrm{C}$ the phospholipids assume a nanoribbon-like structure that forms a higher viscosity interconnected network. The DMPC-DHPC preparation is self-coating, suppressing electroosmotic flow by simply flushing the capillary with the phospholipid [106]. The phospholipid nanogel is roughly one-third of the cost of POP-4TM gels used for human STR analyses [107-109]. The nanogel separation shown in Fig. 3 is of FAM-labeled STRs from the PowerPlex ${ }^{\circledR} 16$ analysis kit [103]. Single-base resolution up to 250 bases was demonstrated with a $10 \%$ phospholipid nanogel [103]. Nanogels diluted to $2.5 \%$ extend the range for precise DNA sizing up to 1500 base pairs [110]. The thermally responsive viscosity can support sieving gradients [103] as well as stacking cartridges that preconcentrate DNA upon injection and can be thermally erased prior to separation [110].

\section{Capillary electrophoresis and DNA aptamers}

\section{Generating DNA aptamers}

DNA recognition elements, also called aptamers, can be tailored to bind biomolecule targets with selectivity and specificity approaching that of antibodies. An aptamer of single-

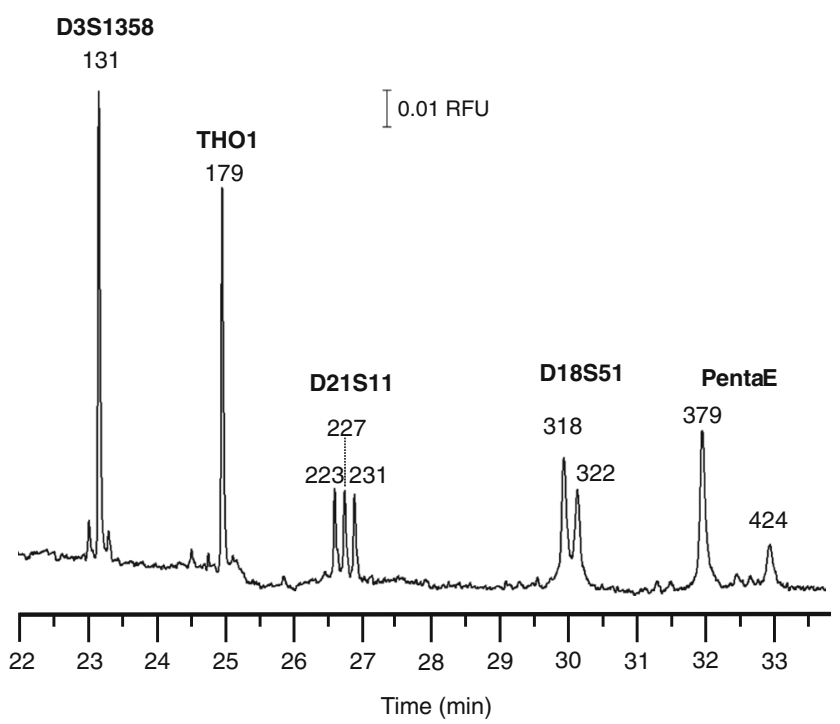

Fig. 3 Separation of the 5 FAM labeled STRs produced from the multiplex PCR amplification of standard DNA template K562. Reprinted with permission from Durney BC, Lounsbury JA, Poe BL, Landers JP, Holland LA (2013) A thermally responsive phospholipid pseudogel: tunable DNA sieving with capillary electrophoresis. Analytical Chemistry 85(14):6617-6625. Copyright 2013 American Chemical Society. stranded DNA spontaneously forms secondary structure that leads to strong aptamer-target molecular binding. Figure 4A depicts the secondary structure of an atrazine aptamer [111] as predicted by $m$-fold [112]. Unlike antibodies, aptamers are stable under the conditions required for robust biosensors. Once aptamer-target binding is realized the temperature can be manipulated to release the target and then refold the aptamer. This thermal reversibility of aptamer structure can be harnessed to reset the biosensor and use it repeatedly. DNA aptamers are produced through a process of iterative enrichment of the DNA-target complex from a DNA library through a method called systematic evolution of ligands by exponential enrichment (SELEX) [113]. Higher-throughput separation techniques play a significant role in the enrichment process. The unique separation capabilities of capillary electrophoresis have led to new strategies for aptamer generation and provide a quantitative means to measure binding affinity of DNA aptamers.

Capillary electrophoresis is used to generate aptamers for targets with an electrophoretic mobility different from that of

\section{a) Secondary Structure of Atrazine Aptamer R12.23}

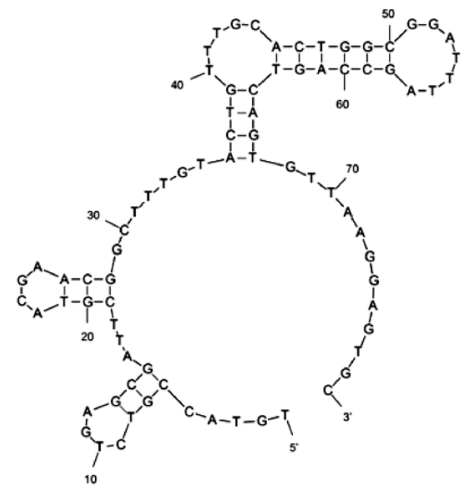

b) Separation of Binding and Non-binding DNA
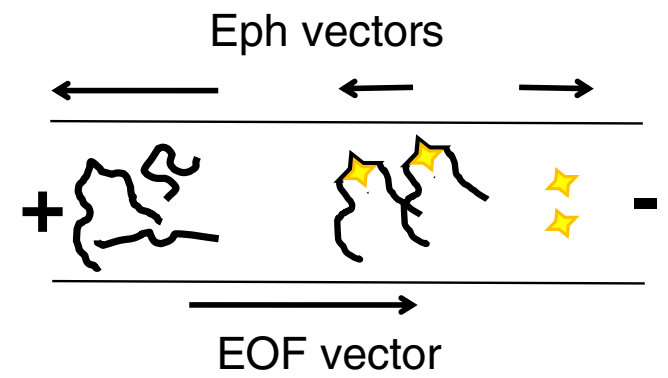

Fig. 4 a An atrazine aptamer is used as an example of how DNA aptamers exploit secondary structure of single-stranded DNA to bind a target. Reprinted from Williams RM, Crihfield CL, Gattu S, Holland LA, Sooter LJ. In vitro selection of a single-stranded DNA molecular recognition element against atrazine (2014) International Journal of Molecular Sciences 15(8):14332-14347, available under a Creative Commons Attribution License. $\mathbf{b}$ The change in migration resulting from aptamer binding to target is depicted 
DNA fragments. The similar electrophoretic mobility of DNA fragments in free zone capillary electrophoresis separations is considered a disadvantage for DNA separations, but is harnessed for this technique. Upon binding to the target, the DNA-target complex undergoes a change in electrophoretic mobility, which shifts the migration time of the complex from that of the non-binding DNA fragments. Figure 5B depicts this change in migration when the target is either positively charged or neutral and the experiment does not suppress electroosmotic flow. The integration of capillary electrophoresis in the SELEX process, as first described by Mendonsa and Bowser [114], is illustrated in Fig. 6A. Non-binding fragments co-migrate in a single unresolved band, whereas binding fragments migrate before or after the non-binding band depending on whether the target molecule increases or decreases the mobility of the DNA-target complex. Fractions are collected from the capillary so that they may be amplified and further enhanced by repetitive rounds of positive or negative selection. Advantages of capillary electrophoresis-SELEX over other SELEX methods are a smaller sample handling volume, faster screening, and most importantly no need to immobilize either the aptamer or the target during selection rounds.

\section{a) SELEX-Capillary Electrophoresis}

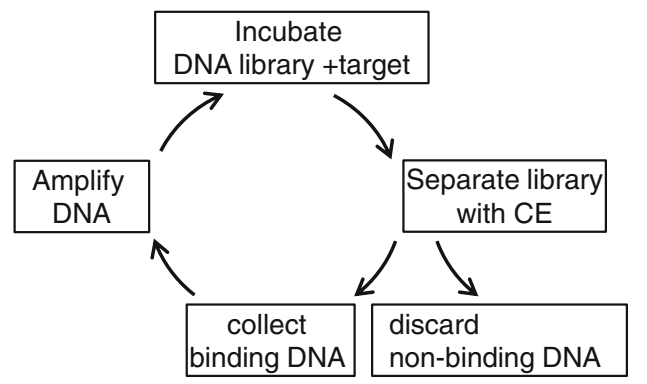

b) non-SELEX-Capillary Electrophoresis

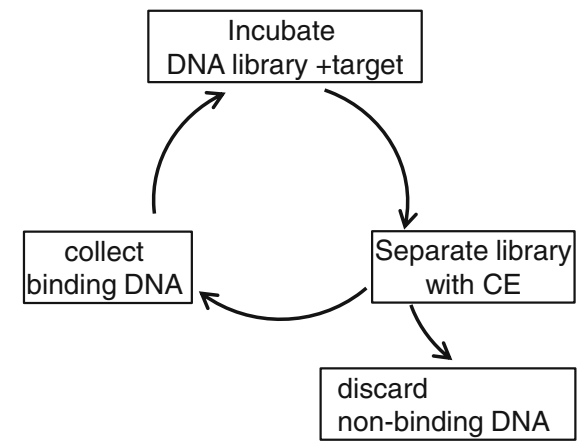

Fig. 5 a Aptamer discovery via capillary electrophoresis-SELEX requires cycles of incubation of DNA with target, removal of nonbinding DNA, and amplification of binding DNA. b Aptamer discovery via non-SELEX-capillary electrophoresis reduces the time required by removing the amplification step between each incubation with target

\section{Capillary electrophoresis-SELEX}

Capillary electrophoresis-SELEX methods [115-120] have recently been used to generate aptamers predominantly for proteins, although work with peptides [121] and small molecules [122] is reported. Innovations in the field of capillary electrophoresis-SELEX continue. The method has been translated into a micro free-flow electrophoresis, which is a twodimensional device in which electrophoresis is applied perpendicularly to hydrodynamic flow to separate binding and non-binding DNA fragments [116]. Integrating the selection into a microfluidic device further reduces the volume required for fraction collection with next-generation sequencing. Previously, observations of unexpected decreases in the rate of aptamer enrichment with successive rounds were attributed to the appearance of short DNA by-products [123]. Bias in the PCR amplification of non-binding fragments over bound fragments leads to inaccurate selection of aptamer candidates. Drawbacks of PCR amplification have led to the use of realtime PCR to decrease the number of enrichment cycles [118].

The method of capillary electrophoresis-SELEX has been adapted to reduce the repetitive selections required to enhance binding so that only a single amplification step is utilized after the capillary electrophoresis enrichment. This alternative method of capillary electrophoresis-non-SELEX integrates DNA selection without amplification as outlined in Fig. 6B [124]. With non-SELEX capillary electrophoresis, regions of free and bound DNA are not fully resolved. The dissociation is evaluated by assessing the relative amount of DNA that is bound, free, or dissociates during the capillary electrophoresis separation [125]. Predictive models have been developed to optimize the approach [126]. Non-SELEX methods have recently been used to generate aptamers for proteins [127-137], although work with lipopolysaccharide [138] is also reported. Emulsion PCR has been reported to reduce accumulation of DNA by-products [132]. The method continues to be refined by combining in-capillary mixing of reactants and affinity analysis [127], and passivating the capillary surface [137]. Other adaptations of capillary electrophoresis for aptamer generation include the integration of reproducible fraction collection with on-column non-covalent fluorescent labeling [139] and next-generation sequencing [140] with capillary isotachophoresis. Innovations in automated fraction collection using ink jet printers and 96-well microtiter plates will further improve the method [119].

\section{Evaluating DNA aptamer binding}

Capillary electrophoresis is a powerful tool to quantitatively measure dissociation constants for aptamers with targets, and excellent reviews of affinity binding methods for aptamers and targets are available [141, 142]. Capillary electrophoresis is well suited to evaluate aptamer affinity when the 
Fig. 6 Obtaining a binding constant for aptamer using a mobility shift, b pre-equilibrium, or $\mathbf{c}$ nonequilibrium capillary electrophoresis methods. a Aptamer and ligand interaction occurs in-capillary, and the binding constant is determined on the basis of the shift in migration time correlating to the ligand concentration. b Aptamer and ligand interaction occur offcapillary, and the amount of bound and free aptamers is monitored in relation to ligand concentration. $\mathbf{c}$ In nonequilibrium capillary electrophoresis of equilibrium mixtures, aptamer and target are in equilibrium off-capillary. Dissociation begins during separation. Binding constants are determined using the decay from the bound and free regions of the electropherogram a) Mobility Shift

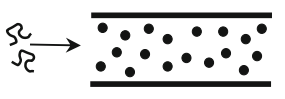

separate with CE in several different ligand concentrations in the buffer and measure mobility shift

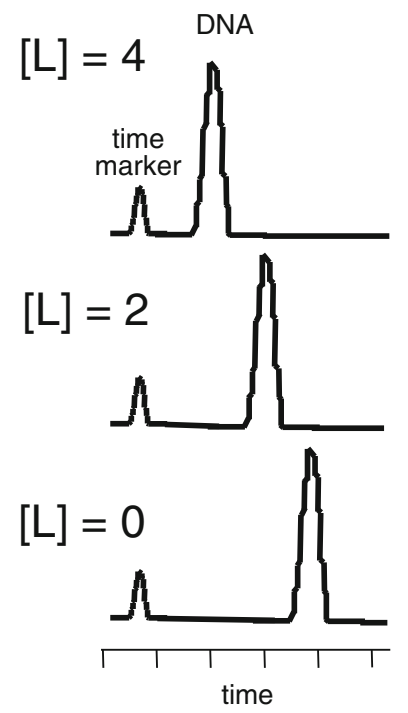

b) Pre-equilibrium

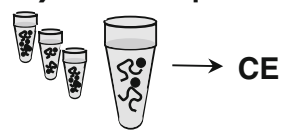

incubate aptamer and ligand separate with $\mathrm{CE}$ quantify bound/free
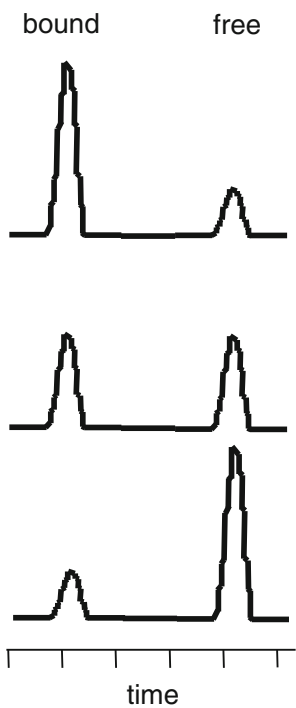

c) NECEEM

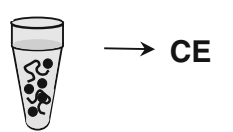

incubate aptamer and ligand separate with $\mathrm{CE}$ quantify using decay from bound and free regions

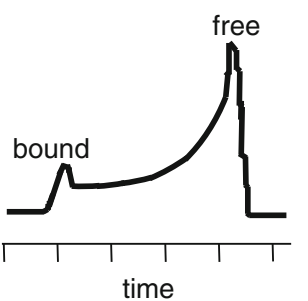

electrophoretic mobility of free and bound aptamer differ significantly because the separations are fast and require working sample volumes of $15 \mu \mathrm{L}$ to deliver injection sample volumes of $2 \mathrm{~nL}$ or less. Methods of assessing dissociation constants with capillary electrophoresis are based on a change in the charge-to-size ratio upon binding, which leads to mobility shift that depends on the rate of association. Protein-aptamer complexes have a large change in mobility, which can be easily detected with electrophoresis. The most common methods are classical mobility shift affinity capillary electrophoresis [143], pre-equilibrium affinity capillary electrophoresis [144], or nonequilibrium capillary electrophoresis of equilibrium mixtures [145]. These processes are depicted in Fig. 6 and discussed in greater detail below.

\section{Classical mobility shift affinity}

Classical mobility shift affinity, shown in Fig. 6A, involves the separation of an aptamer in a background electrolyte devoid of target and then in background electrolyte with increasing concentrations of target. The concentration of aptamer and target determines the amount of time the aptamer is complexed as it migrates in the capillary. The migration time will shift with increasing target concentration as a function of the dissociation constant. An advantage to using measurements of mobility shift to measure aptamer dissociation constants is that the experiment can be used when it is difficult to estimate the concentration of the target (e.g., bacteria [146]). Mobility shift affinity capillary electrophoresis is best suited to aptamer complexes with weak or intermediate binding affinity in order to sample a range of complex migration shifts resulting from fractional complex formation within the time frame of the separation. As a result, the use of mobility shift affinity capillary electrophoresis is not reported frequently to measure aptamer-target affinity, although it has been used to evaluate the effect of interactions between aptamers and metal ions [147].

Pre-incubation equilibrium affinity capillary electrophoresis

Pre-incubation equilibrium affinity capillary electrophoresis (Fig. 6B) requires that aptamer and target are incubated off-capillary. Different concentrations of the target are incubated in a constant concentration of the aptamer. Each incubation shown in Fig. 6B is separated by capillary electrophoresis to quantify the bound and free concentration of aptamer. Pre-equilibrium affinity capillary electrophoresis is used when the aptamer complex does not dissociate significantly during the time frame of the separation. Pre-incubation equilibrium affinity capillary electrophoresis has been applied 
to proteins [114, 116, 117, 123, 148], peptides [121], and small molecules $[117,149]$. An innovative application utilizes a micro free-flow device for affinity capillary electrophoresis as a means to sample the ratio of bound and free aptamer at a wide range of concentrations. The method uses concentration change due to lateral diffusion, internal standards, and twodimensional detection to record concentrations from different line scans obtained throughout the separation [150].

\section{Measurements based on nonequilibrium capillary electrophoresis}

Measurements based on nonequilibrium capillary electrophoresis of equilibrium mixtures (Fig. 6C) involve injecting and then separating a mixture of target and aptamer in the capillary. The complex dissociates throughout the run and the resulting electropherogram does not contain discrete peaks that are baseline resolved. Instead the electropherogram contains zones of fully bound and free aptamer that define an intermediate region reflecting dissociation with increasing run time. Deconvolution of the unresolved peaks and mathematical manipulation provide both the binding constant and decay constant of the DNA aptamer-target [145] and can be utilized when the concentration of the target is unknown [151]. Nonequilibrium capillary electrophoresis of equilibrium mixtures provides information about the dissociation constant and the rate constants in a single run. The method is predominantly used to evaluate protein binding aptamers [115, 120, 124, 127, 129-133, 135-137, 145, 151-153], although measurements of peptides [134], small molecules including lipopolysaccharide [138], and quinine [154] have recently been reported.

\section{Future directions of emerging and expanding technology}

Innovations in the development of capillary electrophoresis methods for DNA separations have emerged beyond sizing DNA, generating aptamers, or characterizing the affinity binding. Several recent research advances in mechanisms of DNA separations, novel sieving gels, and even artificial gels enable new areas of scientific discovery. A few of these techniques are highlighted as areas to watch for future expansion.

\section{Improved analyses based on composition}

A recent report outlines a separation of the set of singlestranded DNA, 76 nucleotides in length differing in sequence by $2-5$ bases per DNA strand. The separations were performed in running buffer containing different phosphatederived sodium salts. The presence of guanosine 5'monophosphate, adenosine 5'-monophosphate, uridine 5'- monophosphate, deoxyguanosine monophosphate, or phosphate supported sequence-based selectivity of DNA fragments which was suggested as an alternative to stability and conformation-based analyses [155]. Metal cation mediatedcapillary electrophoresis, which is sensitive to conformational change [156], generates separation-based aptamer assays of $5 \mu \mathrm{M}$ cocaine detection through conformational change associated with displacement of the aptamer target [157]. DNA aptamers can also be used as labels for indirect molecular detection. The concept of conformational change associated with aptamer-target displacement is utilized for multiplexed separation-based assays [158]. In the absence of the target, aptamers are cleaved by phosphodiesterase I [158]. Aptamer binding stabilizes the DNA aptamer and protects it from enzymatic cleavage [158]. Thus, intact fluorescently labeled aptamer strands indicate binding. The separation is multiplexed by using 23-, 36-, and 49-nucleotide-long aptamers to detect adenosine, ochratoxin $\mathrm{A}$, and tyrosinamide [158].

\section{Improved analyses with transformable gels}

Thermally responsive matrices, such as phospholipid nanogels [103, 110], are ideal for DNA analysis because the material can be loaded into a separation channel under conditions of low viscosity and then switched to a higher viscosity to accommodate the sieving separation. One class of separation matrix includes triblock copolymers of poly(ethylene glycol) (PEG) and poly(propylene glycol) (PPO) that have compositional formulas of $\mathrm{PEG}_{a} \mathrm{PPO}_{b} \mathrm{PEG}_{a}$ and are commonly known as Pluronics. The use of these materials as DNA separation matrices stems from an aqueous micelle structure that allows for higher concentration polymer solutions to be implemented for sieving while keeping a very low viscosity, e.g., a $15 \%$ Pluronic F108 matrix has a viscosity of only $21 \mathrm{cP}$ [159]. From 2009 to 2014 Pluronic matrices were predominantly used for single-strand conformation polymorphism analysis, when multiple fragments with the same length and only slight differences in sequence can be resolved for a cost as low as US\$0.10 per gram [160]. These methods require a matrix that is non-denaturing allowing for the exploitation of subtle differences in mobility due to changes in secondary structure created by DNA sequence variability. The hydrophilic micelle structure of the polyethylene oxide chains in Pluronic matrices provides dynamic surface coating and favorable interactions with DNA analytes in solution, making it possible to resolve fragments on the basis of secondary structural differences. There are 48 total Pluronic formulations; however, only a few are transparent and can be used in conjunction with DNA detection methods [161]. The Pluronic F108 matrix was utilized for the detection of pathogens $[159,161-168]$ or human biomarkers $[169,170]$. 


\section{Artificial matrices}

Artificial matrices can be created with micrometer to submicrometer features fabricated within separation channels with electrically insulating materials. Channels with nanoscale dimensions, pillar arrays, and self-assembling colloidal crystals are examples of artificial matrices. Many studies utilizing pillar arrays examined the effects of geometry [171], size [172], order [173], and space [174, 175] on separation performance. Square and rectangular pillars with different orientations were used to show that electric field distribution, velocity, and motion are impacted by pillar geometry and packing [171]. Improvements in resolution have been obtained by decreasing pillar diameter [172], decreasing convective steering by increasing spacing [174], maintaining order of the array [173], and creating a more uniform electric field through the use of a nanofence rather than a traditional hexagonal pillar array [175]. Motion within sparse hexagonal ordered arrays has been proven to be driven by a non-uniform electric field [176], which causes conformational changes in DNA leading to band broadening [175]. Changing the angle of the applied electric field with post arrays expanded the range of applied voltages for separations and decreased the required separation length [177].

Studies utilizing fabricated obstacles provide an experimental means to elucidate basic principles of DNA separation and provide insight regarding transport. When the separation channel dimension is equal to the persistence length of the DNA molecule $(45 \mathrm{~nm})$ the mobility decreases with increase in DNA length [178]. The relationship holds true for channel dimensions 10 times greater than the persistence length $(450 \mathrm{~nm})$, and supports the assumptions of Ogston transport. However, the opposite trend for DNA mobility (i.e., increase in mobility with increase in DNA length) was observed for a channel of intermediate size $(250 \mathrm{~nm})$ [178]. Understanding this shift in mobility and how it relates to changes in entropy and the degree of interaction between the DNA and the channel wall provide a means to tune the size of a fabricated matrix around particular DNA applications involving separating a specific range of fragment sizes. Along with the physical barriers that impact DNA mobility, ionic strength of the buffer ties to the degree of electrostatic interactions and hydrodynamic confinement between the DNA and the wall of a nano-channel [179, 180]. The field-dependent mobility and DNA trapping mechanisms can be observed at high and low DC electric fields through the use of polyvinylpyrrolidone to decrease the overall width of a channel by forming rigid chain obstructions [181, 182]. Similar results were obtained using glass capillaries with a 750-nm inner diameter, obviating the need for high resolution lithography used to fabricate a nanoslit device [183]. In other studies, colloidal crystal suspensions have been utilized to create artificial matrices, which are more easily fabricated than pillar arrays or nano-slits. The use of monodisperse colloidal crystals is critical for creating uniform pore sizes for optimal resolution and reduced band broadening in comparison to a matrix composed of colloidal particles of differing size [184]. These technologies hold the potential to generate low-cost, high-performance, fabricated microfluidics for DNA analyses and eliminate the need for a gel sieving matrix.

Capillary electrophoresis plays a critical role in the development of DNA analysis technologies. It has been the method of choice for DNA analysis techniques commonly used for sequencing, sizing, and aptamer discovery and affinity studies. As novel approaches emerge, capillary electrophoresis techniques evolve from development stages to validated and applied methods. Still, the development of techniques to better understand separations in capillary, such as artificial matrices, suggests that optimization of capillary electrophoresis methods will continue to be pivotal in expanding the field of DNA analysis.

Acknowledgments This report is based upon work supported by the National Science Foundation under Grant No. CHE1212537. We acknowledge support from the National Science Foundation, including support for CLC through the WVNano Graduate Fellowship Program (Cooperative Agreement 1003907).

Open Access This article is distributed under the terms of the Creative Commons Attribution 4.0 International License (http://creativecommons.org/licenses/by/4.0/), which permits unrestricted use, distribution, and reproduction in any medium, provided you give appropriate credit to the original author(s) and the source, provide a link to the Creative Commons license, and indicate if changes were made.

\section{References}

1. Jorgenson JW, Lukacs KD (1981) Zone electrophoresis in opentubular glass capillaries. Anal Chem 53(8):1298-1302

2. Jorgenson JW, Lukacs KD (1981) Free-zone electrophoresis in glass capillaries. Clin Chem 27(9):1551-1553

3. Cohen AS, Najarian D, Smith JA, Karger BL (1988) Rapid separation of DNA restriction fragments using capillary electrophoresis. J Chromatogr A 458:323-333

4. Kasper TJ, Melera M, Gozel P, Brownlee RG (1988) Separation and detection of DNA by capillary electrophoresis. J Chromatogr A 458:303-312

5. Swerdlow H, Wu S, Harke H, Dovichi NJ (1990) Capillary gel electrophoresis for DNA sequencing: laser-induced fluorescence detection with the sheath flow cuvette. J Chromatogr A 516(1):61-67

6. Swerdlow H, Gesteland R (1990) Capillary gel electrophoresis for rapid, high resolution DNA sequencing. Nucleic Acids Res 18(6): 1415-1419

7. Luckey JA, Drossman H, Kostichka AJ, Mead DA, D'Cunha J, Norris TB, Smith LM (1990) High speed DNA sequencing by capillary electrophoresis. Nucleic Acids Res 18(15):4417-4421

8. Drossman H, Luckey JA, Kostichka AJ, D'Cunha J, Smith LM (1990) High-speed separations of DNA sequencing reactions by capillary electrophoresis. Anal Chem 62(9):900-903

9. Heiger DN, Cohen AS, Karger BL (1990) Separation of DNA restriction fragments by high performance capillary 
electrophoresis with low and zero crosslinked polyacrylamide using continuous and pulsed electric fields. J Chromatogr A 516(1):33-48

10. Cohen AS, Najarian DR, Karger BL (1990) Separation and analysis of DNA sequence reaction products by capillary gel electrophoresis. J Chromatogr A 516(1):49-60

11. Venter JC, Adams MD, Myers EW, Li PW, Mural RJ, Sutton GG, Smith HO, Yandell M, Evans CA, Holt RA et al (2001) The sequence of the human genome. Science 291(5507):1304-1351

12. Lazaruk K, Walsh PS, Oaks F, Gilbert D, Rosenblum BB, Menchen S, Scheibler D, Wenz HM, Holt C, Wallin J (1998) Genotyping of forensic short tandem repeat (STR) systems based on sizing precision in a capillary electrophoresis instrument. Electrophoresis 19(1):86-93

13. Butler JM, Buel E, Crivellente F, McCord BR (2004) Forensic DNA typing by capillary electrophoresis using the ABI Prism 310 and 3100 genetic analyzers for STR analysis. Electrophoresis 25(10-11):1397-1412

14. Woolley AT, Mathies RA (1994) Ultra-high-speed DNA fragment separations using microfabricated capillary array electrophoresis chips. Proc Natl Acad Sci 91(24):11348-11352

15. Woolley AT, Mathies RA (1995) Ultra-high-speed DNA sequencing using capillary electrophoresis chips. Anal Chem 67(20): 3676-3680

16. Woolley AT, Hadley D, Landre P, deMello AJ, Mathies RA, Northrup MA (1996) Functional integration of PCR amplification and capillary electrophoresis in a microfabricated DNA analysis device. Anal Chem 68(23):4081-4086

17. Effenhauser CS, Bruin GJM, Paulus A, Ehrat M (1997) Integrated capillary electrophoresis on flexible silicone microdevices: analysis of DNA restriction fragments and detection of single DNA molecules on microchips. Anal Chem 69(17):3451-3457

18. Chao T-C, Bhattacharya S, Ros A (2012) Microfluidic gel electrophoresis in the undergraduate laboratory applied to food analysis. J Chem Educ 89(1):125-129

19. Piunno PAE, Zetina A, Chu N, Tavares AJ, Noor MO, Petryayeva E, Uddayasankar U, Veglio A (2014) A comprehensive microfluidics device construction and characterization module for the advanced undergraduate analytical chemistry laboratory. J Chem Educ 91(6):902-907

20. Quesada MA (1997) Replaceable polymers in DNA sequencing by capillary electrophoresis. Curr Opin Biotechnol 8(1):82-93

21. Chiari M, Melis A (1998) Low viscosity DNA sieving matrices for capillary electrophoresis. Trends Anal Chem; TrAC 17(10):623632

22. Albarghouthi MN, Barron AE (2000) Polymeric matrices for DNA sequencing by capillary electrophoresis. Electrophoresis 21(18):4096-4111

23. Buchholz BA, Shi W, Barron AE (2002) Microchannel DNA sequencing matrices with switchable viscosities. Electrophoresis 23(10):1398-1409

24. Chung M, Kim D, Herr AE (2014) Polymer sieving matrices in microanalytical electrophoresis. Analyst 139(22):5635-5654

25. Guttman A (2003) Gel and polymer-solution mediated separation of biopolymers by capillary electrophoresis. J Chromatogr Sci 41(9):449-459

26. Barbier V, Viovy J-L (2003) Advanced polymers for DNA separation. Curr Opin Biotechnol 14(1):51-57

27. Karger BL, Snyder LR, Horvath C (1973) An introduction to separation science. Wiley, New York, pp 147-148

28. Ettre LS (1993) Nomenclature for chromatography (IUPAC Recommendations 1993). Pure Appl Chem 65(4):819-872

29. Luckey JA, Norris TB, Smith LM (1993) Analysis of resolution in DNA sequencing by capillary gel electrophoresis. J Phys Chem 97(12):3067-3075
30. Manabe T, Chen N, Terabe S, Yohda M, Endo I (1994) Effects of linear polyacrylamide concentrations and applied voltages on the separation of oligonucleotides and DNA sequencing fragments by capillary electrophoresis. Anal Chem 66(23):4243-4252

31. Goetzinger W, Kotler L, Carrilho E, Ruiz-Martinez MC, SalasSolano O, Karger BL (1998) Characterization of high molecular mass linear polyacrylamide powder prepared by emulsion polymerization as a replaceable polymer matrix for DNA sequencing by capillary electrophoresis. Electrophoresis 19(2):242-248

32. Li W, Ma Y, Gan Z, Ling X, Yang Z (2011) Qualitative and quantitative determination of oligonucleotides by non-gel capillary electrophoresis. Chromatographia 73(5-6):579-582

33. Hjertén S (1985) High-performance electrophoresis: elimination of electroendosmosis and solute adsorption. J Chromatogr A 347: 191-198

34. Yeung SHI, Liu P, Del Bueno N, Greenspoon SA, Mathies RA (2009) Integrated sample cleanup - capillary electrophoresis microchip for high-performance short tandem repeat genetic analysis. Anal Chem 81(1):210-217

35. Jia Z-P, Wang R, Chen Q-Y, Xie H, Ma J, Liu Y-Y, Wang J (2009) $\mathrm{CE}$ of small DNA fragments using linear polyacrylamide matrices. Chromatographia 70(7-8):1127-1134

36. Thaitrong N, Toriello NM, Del Bueno N, Mathies RA (2009) Polymerase chain reaction-capillary electrophoresis genetic analysis microdevice with in-line affinity capture sample injection. Anal Chem 81(4):1371-1377

37. Jung JH, Kim G-Y, Seo TS (2011) An integrated passive micromixer-magnetic separation-capillary electrophoresis microdevice for rapid and multiplex pathogen detection at the single-cell level. Lab Chip 11(20):3465-3470

38. Beyor N, Yi L, Seo TS, Mathies RA (2009) Integrated capture, concentration, polymerase chain reaction, and capillary electrophoretic analysis of pathogens on a chip. Anal Chem 81(9): 3523-3528

39. Kim YT, Choi JY, Chen Y, Seo TS (2013) Integrated slidable and valveless polymerase chain reaction-capillary electrophoresis microdevice for pathogen detection. R Soc Chem Adv 3(22): 8461-8467

40. Thaitrong N, Liu P, Briese T, Lipkin WI, Chiesl TN, Higa Y, Mathies RA (2010) Integrated capillary electrophoresis microsystem for multiplex analysis of human respiratory viruses. Anal Chem 82(24):10102-10109

41. Njoroge SK, Witek MA, Battle KN, Immethun VE, Hupert ML, Soper SA (2011) Integrated continuous flow polymerase chain reaction and micro-capillary electrophoresis system with bioaffinity preconcentration. Electrophoresis 32(22):3221-3232

42. Njoroge SK, Witek MA, Hupert ML, Soper SA (2010) Microchip electrophoresis of Alu elements for gender determination and inference of human ethnic origin. Electrophoresis 31(6):981-990

43. Hestekin CN, Lin JS, Senderowicz L, Jakupciak JP, O'Connell C, Rademaker A, Barron AE (2011) Blinded study determination of high sensitivity and specificity microchip electrophoresis-SSCP/ HA to detect mutations in the p53 gene. Electrophoresis 32(21): 2921-2929

44. Kotani A, Witek MA, Osiri JK, Wang H, Sinville R, Pincas H, Barany F, Soper SA (2012) EndoV/DNA ligase mutation scanning assay using microchip capillary electrophoresis and dual-color laser-induced fluorescence detection. Anal Methods 4(1):58-64

45. Rosenblum BB, Oaks F, Menchen S, Johnson B (1997) Improved single-strand DNA sizing accuracy in capillary electrophoresis. Nucleic Acids Res 25(19):3925-3929

46. Wenz H, Robertson JM, Menchen S, Oaks F, Demorest DM, Scheibler D, Rosenblum BB, Wike C, Gilbert DA, Efcavitch JW (1998) High-precision genotyping by denaturing capillary electrophoresis. Genome Res 8(1):69-80 
47. Madabhushi RS (1998) Separation of 4-color DNA sequencing extension products in noncovalently coated capillaries using low viscosity polymer solutions. Electrophoresis 19(2):224-230

48. Fredlake CP, Hert DG, Root BE, Barron AE (2008) Polymer systems designed specifically for DNA sequencing by microchip electrophoresis: a comparison with commercially available materials. Electrophoresis 29(23):4652-4662

49. http://www.lifetechnologies.com/order/catalog/product/402838. Accessed 15 Jan 2015

50. Nai YH, Jones RC, Breadmore MC (2013) Sieving polymer synthesis by reversible addition fragmentation chain transfer polymerization. Electrophoresis 34(22-23):3189-3197

51. Fredlake CP, Hert DG, Niedringhaus TP, Lin JS, Barron AE (2012) Divergent dispersion behavior of ssDNA fragments during microchip electrophoresis in pDMA and LPA entangled polymer networks. Electrophoresis 33(9-10): 1411-1420

52. Frumkin D, Wasserstrom A, Budowle B, Davidson A (2011) DNA methylation-based forensic tissue identification. Forensic Sci Int Gen 5(5):517-524

53. Li Y, Zhang J, Wei W, Wang Z, Prinz M, Hou Y (2014) A strategy for co-analysis of microRNAs and DNA. Forensic Sci Int Gen 12: 24-29

54. Wasserstrom A, Frumkin D, Davidson A, Shpitzen M, Herman Y, Gafny R (2013) Demonstration of DSI-semen - a novel DNA methylation-based forensic semen identification assay. Forensic Sci Int Gen 7(1):136-142

55. Nakanishi H, Hara M, Takahashi S, Takada A, Saito K (2014) Evaluation of forensic examination of extremely aged seminal stains. Legal Med 16(5):303-307

56. Tie J, Uchigasaki S (2014) Detection of short tandem repeat polymorphisms from human nails using direct polymerase chain reaction method. Electrophoresis 35(21-22):3188-3192

57. Hurth C, Gu J, Aboud M, Estes MD, Nordquist AR, McCord B, Zenhausern F (2012) Direct loading of polymer matrices in plastic microchips for rapid DNA analysis: a comparative study. Electrophoresis 33(16):2604-2611

58. Hopwood AJ, Hurth C, Yang J, Cai Z, Moran N, Lee-Edghill JG, Nordquist A, Lenigk R, Estes MD, Haley JP, McAlister CR, Chen X, Brooks C, Smith S, Elliott K, Koumi P, Zenhausern F, Tully G (2010) Integrated microfluidic system for rapid forensic DNA analysis: sample collection to DNA profile. Anal Chem 82(16): 6991-6999

59. Yang J, Brooks C, Estes MD, Hurth CM, Zenhausern F (2014) An integratable microfluidic cartridge for forensic swab samples lysis. Forensic Sci Int Gen 8(1):147-158

60. Rawal M, Hoff E, Aas-Pedersen L, Haugum K, Lindstedt B-A (2010) Rapid multiple-locus variable-number tandem-repeats analysis of Shigella spp. using multicolour capillary electrophoresis. J Microbiol Method 83(3):279-285

61. Radtke A, Lindstedt B-A, Afset JE, Bergh K (2010) Rapid multiple-locus variant-repeat assay (MLVA) for genotyping of Streptococcus agalactiae. J Clin Microbiol 48(7):2502-2508

62. Du X-F, Xiao M, Liang H-Y, Sun Z, Jiang Y-H, Chen G-Y, Meng X-Y, Zou G-L, Zhang L, Liu Y-L, Zhang H, Sun H-L, Jiang X-F, $\mathrm{Xu}$ Y-C (2014) An improved MLVF method and its comparison with traditional MLVF, spa typing, MLST/SCCmec and PFGE for the typing of methicillin-resistant Staphylococcus aureus. Int J Mol Sci 15(1):725-742

63. Janezic S, Indra A, Allerberger F, Rupnik M (2011) Use of different molecular typing methods for the study of heterogeneity within Clostridium difficile toxinotypes V and III. J Med Microbiol 60(8): 1101-1107

64. Chen S, Li J, Saleh-Lakha S, Allen V, Odumeru J (2011) Multiplelocus variable number of tandem repeat analysis (MLVA) of Listeria monocytogenes directly in food samples. Int J Food Microbiol 148(1):8-14
65. Sobral D, Le Cann P, Gerard A, Jarraud S, Lebeau B, LoisyHamon F, Vergnaud G, Pourcel C (2011) High-throughput typing method to identify a non-outbreak-involved Legionella pneumophila strain colonizing the entire water supply system in the town of Rennes, France. Appl Environ Microbiol 77(19): 6899-6907

66. Sobral D, Mariani-Kurkdjian $\mathrm{P}$, Bingen E, Vu-Thien $\mathrm{H}$, Hormigos K, Lebeau B, Loisy-Hamon F, Munck A, Vergnaud G, Pourcel C (2012) A new highly discriminatory multiplex capillary-based MLVA assay as a tool for the epidemiological survey of Pseudomonas aeruginosa in cystic fibrosis patients. Eur J Clin Microbiol Infect Dis 31(9): 2247-2256

67. Duodu S, Wan X, Tandstad NM, Larsson P, Myrtennäs K, Sjödin A, Forsman M, Colquhoun DJ (2013) An improved multiplelocus variable-number of tandem repeat analysis (MLVA) for the fish pathogen Francisella noatunensis using capillary electrophoresis. BMC Vet Res 9(1):1-9

68. Sihvonen LM, Toivonen S, Haukka K, Kuusi M, Skurnik M, Siitonen A (2011) Multilocus variable-number tandem-repeat analysis, pulsed-field gel electrophoresis, and antimicrobial susceptibility patterns in discrimination of sporadic and outbreakrelated strains of Yersinia enterocolitica. BMC Microbiol 11(1): $42-51$

69. Cressier B, Bissonnette N (2011) Assessment of an extraction protocol to detect the major mastitis-causing pathogens in bovine milk. J Dairy Sc 94(5):2171-2184

70. Basak S, Ehtesham NZ, Sesikeran B, Ghosh S (2014) Detection and identification of transgenic elements by fluorescent-PCRbased capillary gel electrophoresis in genetically modified cotton and soybean. J AOAC Int 97(1):159-165

71. Shin GW, Cho YS, Hwang HS, Oh M-H, Nam HG, Park JH, Jung GY (2009) A new single-step quantitative pathogen detection system: template-tagging followed by multiplex asymmetric PCR using common primers and CE-SSCP. Electrophoresis 30(15): 2728-2736

72. Tian H, Landers JP (2002) Hydroxyethylcellulose as an effective polymer network for DNA analysis in uncoated glass microchips: optimization and application to mutation detection via heteroduplex analysis. Anal Biochem 309(2):212-223

73. http://www.sigmaaldrich.com/catalog/product/aldrich/434981? lang $=$ en\&region=US. Accessed 15 Jan 2015

74. Bashkin J, Marsh M, Barker D, Johnston R (1996) DNA sequencing by capillary electrophoresis with a hydroxyethylcellulose sieving buffer. Appl Theor Electrophor 6(1):23-28

75. Li Z, Liu C, Yamaguchi Y, Ni Y, You Q, Dou X (2014) Capillary electrophoresis of a wide range of DNA fragments in a mixed solution of hydroxyethyl cellulose. Anal Methods 6(8):24732477

76. García-Cañas V, Mondello M, Cifuentes A (2010) Simultaneous detection of genetically modified organisms by multiplex ligationdependent genome amplification and capillary gel electrophoresis with laser-induced fluorescence. Electrophoresis 31(13):2249 2259

77. Sun M, Lin JS, Barron AE (2011) Ultrafast, efficient separations of large-sized dsDNA in a blended polymer matrix by microfluidic chip electrophoresis: a design of experiments approach. Electrophoresis 32(22):3233-3240

78. Takahashi T, Kawana J, Tamura Y, Hoshino H (2013) Dynamic coating capillary electrophoresis for separation of humic acid using mixture solution of non-ionic polymers both as coating agent and separation medium. Anal Sci 29(11):1099-1102

79. Eugênio PFM, Carrilho E (2009) Evaluation of capillaries with different inner coatings for DNA analysis using dilute polymer 
solutions by capillary electrophoresis. J Braz Chem Soc 20(10): $1833-1840$

80. http://www.sigmaaldrich.com/catalog/product/sigma/ pvp360?lang=en\&region=US. Accessed 23 April 2015

81. Gao Q, Yeung ES (1998) A matrix for DNA separation: genotyping and sequencing using poly(vinylpyrrolidone) solution in uncoated capillaries. Anal Chem 70(7):1382-1388

82. Cheng Y-Q, Yao B, Zhang H-D, Fang J, Fang Q (2010) An automated capillary electrophoresis system for high-speed separation of DNA fragments based on a short capillary. Electrophoresis 31(19):3184-3191

83. Lim S, Nan H, Lee M-J, Kang SH (2014) Fast on-site diagnosis of influenza A virus by Palm PCR and portable capillary electrophoresis. J Chromatogr B 963:134-139

84. Shin A, Lee M, Kim S, Kang SH (2012) On-line capillary electrophoresis for enhanced detection sensitivity of feline panleukopenia virus. J Chromatogr B 909:22-25

85. Boulos S, Cabrices O, Blas M, McCord BR (2008) Development of an entangled polymer solution for improved resolution in DNA typing by CE. Electrophoresis 29(23):4695-4703

86. Niedringhaus TP, Milanova D, Kerby MB, Snyder MP, Barron AE (2011) Landscape of next-generation sequencing technologies. Anal Chem 83(12):4327-4341

87. Harismendy O, Ng PC, Strausberg RL, Wang X, Stockwell TB, Beeson KY, Schork NJ, Murray SS, Topol EJ, Levy S, Frazer KA (2009) Evaluation of next generation sequencing platforms for population targeted sequencing studies. Genome Biol 10(3):R32

88. Quail MA, Kozarewa I, Smith F, Scally A, Stephens PJ, Durbin R, Swerdlow H, Turner DJ (2008) A large genome center's improvements to the Illumina sequencing system. Nat Methods 5(12): $1005-1010$

89. Thaitrong N, Kim H, Renzi RF, Bartsch MS, Meagher RJ, Patel KD (2012) Quality control of next-generation sequencing library through an integrative digital microfluidic platform. Electrophoresis 33(23):3506-3513

90. Haynes RD, Meagher RJ, Barron AE (2011) A chemically synthesized peptoid-based drag-tag enhances free-solution DNA sequencing by capillary electrophoresis. Peptide Sci 96(5):702-707

91. Lin JS, Albrecht JC, Meagher RJ, Wang X, Barron AE (2011) Completely monodisperse, highly repetitive proteins for bioconjugate capillary electrophoresis: development and characterization. Biomacromolecules 12(6):2275-2284

92. Albrecht JC, Lin JS, Barron AE (2010) A 265-base DNA sequencing read by capillary electrophoresis with no separation matrix. Anal Chem 83(2):509-515

93. Albrecht JC, Kerby MB, Niedringhaus TP, Lin JS, Wang X, Barron AE (2011) Free-solution electrophoretic separations of DNA-drag-tag conjugates on glass microchips with no polymer network and no loss of resolution at increased electric field strength. Electrophoresis 32(10):1201-1208

94. Fahrenkopf MA, Mukherjee T, Ydstie BE, Schneider JW (2014) Optimization of ELFSE DNA sequencing with EOF counterflow and microfluidics. Electrophoresis 35(23):3408-3414

95. Li X, Zhan Z, Zhang S, Chen H (2009) Enzyme enhanced quantitative determination of multiple DNA targets based on capillary electrophoresis. J Chromatogr A 1216(12):2567-2573

96. Tsukada H, Kundu LM, Matsuoka Y, Kanayama N, Takarada T, Maeda M (2013) Quantitative single-nucleotide polymorphism analysis in secondary-structured DNA by affinity capillary electrophoresis using a polyethylene glycol-peptide nucleic acid block copolymer. Anal Biochem 433(2):150-152

97. Desmarais SM, Leitner T, Barron AE (2012) Quantitative experimental determination of primer-dimer formation risk by freesolution conjugate electrophoresis. Electrophoresis 33(3):483491
98. Liu P, Li X, Greenspoon SA, Scherer JR, Mathies RA (2011) Integrated DNA purification, PCR, sample cleanup, and capillary electrophoresis microchip for forensic human identification. Lab Chip 11(6): 1041-1048

99. Bienvenue JM, Legendre LA, Ferrance JP, Landers JP (2010) An integrated microfluidic device for DNA purification and PCR amplification of STR fragments. Forensic Sci Int Gen 4(3):178-186

100. Duarte GRM, Coltro WKT, Borba JC, Price CW, Landers JP, Carrilho E (2012) Disposable polyester-toner electrophoresis microchips for DNA analysis. Analyst 137(11):2692-2698

101. Le Roux D, Root BE, Reedy CR, Hickey JA, Scott ON, Bienvenue JM, Landers JP, Chassagne L, de Mazancourt P (2014) DNA analysis using an integrated microchip for multiplex PCR amplification and electrophoresis for reference samples. Anal Chem 86(16):8192-8199

102. Geng T, Novak R, Mathies RA (2013) Single-cell forensic short tandem repeat typing within microfluidic droplets. Anal Chem 86(1):703-712

103. Durney BC, Lounsbury JA, Poe BL, Landers JP, Holland LA (2013) A thermally responsive phospholipid pseudogel: tunable DNA sieving with capillary electrophoresis. Anal Chem 85(14): $6617-6625$

104. Tuntevski K, Durney BC, Snyder AK, LaSala PR, Nayak AP, Green BJ, Beezhold DH, Rio RV, Holland LA, Lukomski S (2013) Aspergillus collagen-like genes ( $a c l)$ : identification, sequence polymorphism, and assessment for PCR-based pathogen detection. Appl Environ Microbiol 79(24):7882-7895

105. Wu X, Langan TJ, Durney BC, Holland LA (2012) Thermally responsive phospholipid preparations for fluid steering and separation in microfluidics. Electrophoresis 33(17):2674-2681

106. White CM, Luo R, Archer-Hartmann SA, Holland LA (2007) Electrophoretic screening of ligands under suppressed EOF with an inert phospholipid coating. Electrophoresis 28(17):3049-3055

107. http://avantilipids.com/index.php?option $=$ com content\&view= article $\&$ id $=206 \&$ Itemid $=206 \&$ catnumber $=8503051,2$ dihexanoyl-sn-glycero-3-phosphocholine 06:0 PC (DHPC), CAS number 34506-67-7, catalog number 850305P. Avanti Polar Lipids, Inc. Accessed 24 Sept 2014

108. http://avantilipids.com/index.php?option $=$ com_content\&view $=$ article $\&$ id $=214 \&$ Itemid $=206 \&$ catnumber $=8503451,2$ ditetradecanoyl-sn-glycero-3-phosphocholine (DMPC) PC(14:0/ 14:0), CAS Number 18194-24-6, catalog number 850345P. Avanti Polar Lipids, Inc. Accessed 24 Sept 2014

109. http://www.lifetechnologies.com/search/global/searchAction. action?query $=$ pop $-4+$ polymer\&resultPage $=1$ \& resultsPerPage $=$ $15 \&$ autocomplete $=$ true POP $-4{ }^{\circledR}$ Polymer for $3130 / 3130 \times 1$ Genetic Analyzers, $7000 \mu \mathrm{l}$ (Applied Biosystems ${ }^{\mathbb{R}}$ ), catalog number 4352755. 2012 Life Technologies Corporation. Accessed 17 Oct 2012

110. Durney BC, Bachert BA, Sloane HS, Lukomski S, Landers JP, Holland LA (2015) Reversible phospholipid nanogels for DNA fragment size determinations up to 1,500 Base pairs and integrated sample stacking. Anal Chim Acta. doi:10.1016/j.aca.2015.03.009

111. Williams RM, Crihfield CL, Gattu S, Holland LA, Sooter LJ (2014) In vitro selection of a single-stranded DNA molecular recognition element against atrazine. Int J Mol Sci 15(8):1433214347

112. Zuker M (2003) Mfold web server for nucleic acid folding and hybridization prediction. Nucleic Acids Res 31(13):3406-3415

113. Tuerk C, Gold L (1990) Systematic evolution of ligands by exponential enrichment: RNA ligands to bacteriophage T4 DNA polymerase. Science 249(4968):505-510

114. Mendonsa SD, Bowser MT (2003) In vitro evolution of functional DNA using capillary electrophoresis. J Am Chem Soc 126(1):20 21 
115. Tran DT, Janssen KPF, Pollet J, Lammertyn E, Anné J, Van Schepdael A, Lammertyn J (2010) Selection and characterization of DNA aptamers for egg white lysozyme. Molecules 15(3):11271140

116. Jing M, Bowser MT (2011) Isolation of DNA aptamers using micro free flow electrophoresis. Lab Chip 11(21):3703-3709

117. Cella LN, Sanchez P, Zhong W, Myung NV, Chen W, Mulchandani A (2010) Nano aptasensor for protective antigen toxin of anthrax. Anal Chem 82(5):2042-2047

118. Ruff P, Pai RB, Storici F (2012) Real-time PCR-coupled CESELEX for DNA aptamer selection. ISRN Mol Biol 2012:9

119. Huge BJ, Flaherty RJ, Dada OO, Dovichi NJ (2014) Capillary electrophoresis coupled with automated fraction collection. Talanta 130:288-293

120. Tran DT, Knez K, Janssen KP, Pollet J, Spasic D, Lammertyn J (2013) Selection of aptamers against Ara h 1 protein for FO-SPR biosensing of peanut allergens in food matrices. Biosens Bioelectron 43:245-251

121. Rose CM, Hayes MJ, Stettler GR, Hickey SF, Axelrod TM, Giustini NP, Suljak SW (2010) Capillary electrophoretic development of aptamers for a glycosylated VEGF peptide fragment. Analyst 135(11):2945-2951

122. Yang J, Bowser MT (2012) Capillary electrophoresis-SELEX selection of catalytic DNA aptamers for a small-molecule porphyrin target. Anal Chem 85(3):1525-1530

123. Jing M, Bowser MT (2013) Tracking the emergence of high affinity aptamers for $\mathrm{rhVGF}_{165}$ during capillary electrophoresissystematic evolution of ligands by exponential enrichment using high throughput sequencing. Anal Chem 85(22):10761-10770

124. Berezovski M, Musheev M, Drabovich A, Krylov SN (2006) Non-SELEX selection of aptamers. J Am Chem Soc 128(5): 1410-1411

125. Cherney LT, Kanoatov M, Krylov SN (2011) Method for determination of peak areas in nonequilibrium capillary electrophoresis of equilibrium mixtures. Anal Chem 83(22):8617-8622

126. Yu X, Yu Y (2014) A mathematical analysis of the selective enrichment of NECEEM-based non-SELEX. Appl Biochem Biotechnol 173(8):2019-2027

127. Yunusov D, So M, Shayan S, Okhonin V, Musheev MU, Berezovski MV, Krylov SN (2009) Kinetic capillary electrophoresis-based affinity screening of aptamer clones. Anal Chim Acta 631(1):102-107

128. Kasahara Y, Irisawa Y, Fujita H, Yahara A, Ozaki H, Obika S, Kuwahara M (2013) Capillary electrophoresis-systematic evolution of ligands by exponential enrichment selection of base- and sugar-modified DNA aptamers: target binding dominated by 2'-O, 4'-C-methylene-bridged/locked nucleic acid primer. Anal Chem 85(10):4961-4967

129. Ashley J, Li SFY (2013) Three-dimensional selection of leptin aptamers using capillary electrophoresis and implications for clone validation. Anal Biochem 434(1):146-152

130. Tok J, Lai J, Leung T, Li SFY (2010) Selection of aptamers for signal transduction proteins by capillary electrophoresis. Electrophoresis 31(12):2055-2062

131. Krylova SM, Dove PM, Kanoatov M, Krylov SN (2011) Slowdissociation and slow-recombination assumptions in nonequilibrium capillary electrophoresis of equilibrium mixtures. Anal Chem 83(19):7582-7585

132. Yufa R, Krylova SM, Bruce C, Bagg EA, Schofield CJ, Krylov SN (2015) Emulsion PCR significantly improves nonequilibrium capillary electrophoresis of equilibrium mixtures-based aptamer selection: allowing for efficient and rapid selection of aptamer to unmodified ABH2 protein. Anal Chem 87(2):1411-1419

133. Javaherian S, Musheev MU, Kanoatov M, Berezovski MV, Krylov SN (2009) Selection of aptamers for a protein target in cell lysate and their application to protein purification. Nucleic Acids Res 37(8), e62

134. Kanoatov M, Javaherian S, Krylov SN (2010) Selection of aptamers for a non-DNA binding protein in the context of cell lysate. Anal Chim Acta 681(1-2):92-97

135. Ashley J, Ji K, Li SFY (2012) Selection of bovine catalase aptamers using non-SELEX. Electrophoresis 33(17):2783-2789

136. Krylova SM, Karkhanina AA, Musheev MU, Bagg EAL, Schofield CJ, Krylov SN (2011) DNA aptamers for as analytical tools for the quantitative analysis of DNA-dealkylating enzymes. Anal Biochem 414(2):261-265

137. de Jong S, Epelbaum N, Liyanage R, Krylov SN (2012) A semipermanent coating for preventing protein adsorption at physiological $\mathrm{pH}$ in kinetic capillary electrophoresis. Electrophoresis 33(16):2584-2590

138. Kim S-E, Su W, Cho M, Lee Y, Choe W-S (2012) Harnessing aptamers for electrochemical detection of endotoxin. Anal Biochem 424(1):12-20

139. Riley KR, Saito S, Gagliano J, Colyer CL (2014) Facilitating aptamer selection and collection by capillary transient isotachophoresis with laser-induced fluorescence detection. J Chromatogr A 1368:183-189

140. Riley K, Gagliano J, Xiao J, Libby K, Saito S, Yu G, Cubicciotti R, Macosko J, Colyer C, Guthold M, Bonin K (2015) Combining capillary electrophoresis and next-generation sequencing for aptamer selection. Anal Bioanal Chem 1-6

141. Jing M, Bowser MT (2011) Methods for measuring aptamerprotein equilibria: a review. Anal Chim Acta 686(1-2):9-18

142. Ravelet C, Grosset C, Peyrin E (2006) Liquid chromatography, electrochromatography and capillary electrophoresis applications of DNA and RNA aptamers. J Chromatogr A 1117(1):1-10

143. Chu YH, Avila LZ, Biebuyck HA, Whitesides GM (1992) Use of affinity capillary electrophoresis to measure binding constants of ligands to proteins. J Med Chem 35(15):2915-2917

144. Heegaard NHH, Robey FA (1992) Use of capillary zone electrophoresis to evaluate the binding of anionic carbohydrates to synthetic peptides derived from human serum amyloid $\mathrm{P}$ component. Anal Chem 64:2479-2482

145. Berezovski M, Krylov SN (2002) Nonequilibrium capillary electrophoresis of equilibrium mixtures - a single experiment reveals equilibrium and kinetic parameters of protein - DNA interactions. J Am Chem Soc 124(46):13674-13675

146. Meng C, Zhao X, Qu F, Mei F, Gu L (2014) Interaction evaluation of bacteria and protoplasts with single-stranded deoxyribonucleic acid library based on capillary electrophoresis. J Chromatogr A 1358:269-276

147. Girardot M, Gareil P, Varenne A (2010) Interaction study of a lysozyme-binding aptamer with mono- and divalent cations by ACE. Electrophoresis 31(3):546-555

148. Nie H, Chen Y, Lü C, Liu Z (2013) Efficient selection of glycoprotein-binding DNA aptamers via boronate affinity monolithic capillary. Anal Chem 85(17):8277-8283

149. Langan TJ, Nyakubaya VT, Casto LD, Dolan TD, ArcherHartmann SA, Yedlapalli SL, Sooter LJ, Holland LA (2012) Assessment of aptamer-steroid binding using stacking-enhanced capillary electrophoresis. Electrophoresis 33(5):866-869

150. Turgeon RT, Fonslow BR, Jing M, Bowser MT (2010) Measuring aptamer equilibria using gradient micro free flow electrophoresis. Anal Chem 82(9):3636-3641

151. Zhang Y-W, Yan H-Y, Fu P, Jiang F, Zhang Y, Wu W-X, Li J-X (2013) Modified capillary electrophoresis based measurement of the binding between DNA aptamers and an unknown concentration target. Anal Bioanal Chem 405(16):5549-5555

152. Krylova SM, Koshkin V, Bagg E, Schofield CJ, Krylov SN (2012) Mechanistic studies on the application of DNA aptamers as 
inhibitors of 2-oxoglutarate-dependent oxygenases. J Med Chem 55(7):3546-3552

153. Drabovich AP, Berezovski M, Okhonin V, Krylov SN (2006) Selection of smart aptamers by methods of kinetic capillary electrophoresis. Anal Chem 78(9):3171-3178

154. Bao J, Krylova SM, Reinstein O, Johnson PE, Krylov SN (2011) Label-free solution-based kinetic study of aptamer-small molecule interactions by kinetic capillary electrophoresis with UV detection revealing how kinetics control equilibrium. Anal Chem 83(22): $8387-8390$

155. Zhang X, McGown LB (2013) Sequence-based separation of single-stranded DNA using nucleotides in capillary electrophoresis: focus on phosphate. Electrophoresis 34(12):1778-1786

156. Li T, Zhang D, Luo W, Lu M, Wang Z, Song Y, Wang H (2009) Metal cation mediated-capillary electrophoresis of nucleic acids. Anal Chem 82(2):487-490

157. Deng Q-P, Tie C, Zhou Y-L, Zhang X-X (2012) Cocaine detection by structure-switch aptamer-based capillary zone electrophoresis. Electrophoresis 33(9-10):1465-1470

158. Perrier S, Zhu Z, Fiore E, Ravelet C, Guieu V, Peyrin E (2014) Capillary gel electrophoresis-coupled aptamer enzymatic cleavage protection strategy for the simultaneous detection of multiple small analytes. Anal Chem 86(9):4233-4240

159. Kim SJ, Shin GW, Choi SJ, Hwang HS, Jung GY, Seo TS (2010) Triblock copolymer matrix-based capillary electrophoretic microdevice for high-resolution multiplex pathogen detection. Electrophoresis 31(6):1108-1115

160. http://www.sigmaaldrich.com/catalog/product/aldrich/542342? lang=en\&region=US. Accessed $10 \mathrm{Feb} 2015$

161. Shin GW, Hwang HS, Seo SW, Oh M-H, Ryu CY, Salvo CJ, Feldman S, Doh J, Jung GY (2010) A novel pathogen detection system based on high-resolution CE-SSCP using a triblock copolymer matrix. J Sep Sci 33(11):1639-1643

162. Shin GW, Hwang HS, Oh M-H, Doh J, Jung GY (2010) Simultaneous quantitative detection of 12 pathogens using highresolution CE-SSCP. Electrophoresis 31(14):2405-2410

163. Chung B, Shin GW, Hwang HS, Chung Y-J, Jung SW, Jung GY (2012) Precise H1N1 swine influenza detection using stuffer-free multiplex ligation-dependent probe amplification in conformation-sensitive capillary electrophoresis. Anal Biochem 424(1):54-56

164. Chung B, Shin GW, Park CK, Choi W, Chung Y-J, Yoon HK, Jung GY (2014) Rapid and sensitive detection of lower respiratory tract infections by stuffer-free multiplex ligation-dependent probe amplification. Electrophoresis 35(4):511-514

165. Chung B, Shin GW, Choi W, Joo J, Jeon S, Jung GY (2014) Precise characterization method of antibody-conjugated magnetic nanoparticles for pathogen detection using stuffer-free multiplex ligation-dependent probe amplification. Electrophoresis 35(23): 3283-3289

166. Damaso N, Martin L, Kushwaha P, Mills D (2014) F-108 polymer and capillary electrophoresis easily resolves complex environmental DNA mixtures and SNPs. Electrophoresis 35(21-22):32083211

167. Chung B, Shin GW, Na J, Oh M-H, Jung GY (2012) Multiplex quantitative foodborne pathogen detection using high resolution CE-SSCP coupled stuffer-free multiplex ligation-dependent probe amplification. Electrophoresis 33(9-10):1477-1481
168. Shin GW, Kim YT, Heo HY, Chung B, Seo TS, Jung GY (2012) Triblock copolymer-based microchip device for rapid analysis of stuffer-free multiplex ligation-dependent probe amplification products. Electrophoresis 33(23):3574-3578

169. Choi W, Shin GW, Hwang HS, Pack SP, Jung GY, Jung GY (2014) A multiplex single nucleotide polymorphism genotyping method using ligase-based mismatch discrimination and CESSCP. Electrophoresis 35(8):1196-1203

170. Hwang HS, Shin GW, Jung GY, Jung GY (2014) A simple and precise diagnostic method for spinal muscular atrophy using a quantitative SNP analysis system. Electrophoresis 35(23):34023407

171. Chan YC, Zohar Y, Lee Y-K (2009) Effects of embedded submicron pillar arrays in microfluidic channels on large DNA electrophoresis. Electrophoresis 30(18):3242-3249

172. Ou J, Joswiak MN, Carpenter SJ, Dorfman KD (2011) Plasma thinned nanopost arrays for DNA electrophoresis. J Vac Sci Technol A 29(1):011025

173. Olson DW, Dorfman KD (2012) Experimental study of the effect of disorder on DNA dynamics in post arrays during electrophoresis. Phys Rev E 86(4):041909

174. Ou J, Carpenter SJ, Dorfman KD (2010) Onset of channeling during DNA electrophoresis in a sparse ordered post array. Biomicrofluidics 4(1):013203

175. Park S-G, Olson DW, Dorfman KD (2012) DNA electrophoresis in a nanofence array. Lab Chip 12(8):1463-1470

176. Ou J, Cho J, Olson DW, Dorfman KD (2009) DNA electrophoresis in a sparse ordered post array. Phys Rev E 79(6):061904

177. Thomas JDP, Dorfman KD (2014) Tilted post arrays for separating long DNA. Biomicrofluidics 8(3):1-11

178. Wang C-H, Ho CH, Chou YC (2013) Sieving DNA molecules by length dependence in artificial nano-channel matrices. J Appl Phys 113(2):024701-024707

179. Kounovsky-Shafer KL, Hernández-Ortiz JP, Jo K, Odijk T, de Pablo JJ, Schwartz DC (2013) Presentation of large DNA molecules for analysis as nanoconfined dumbbells. Macromolecules 46(20):8356-8368

180. Russell AJ, Del Bonis-O'Donnell JT, Wynne TM, Napoli MT, Pennathur S (2014) Separation behavior of short single- and double-stranded DNA in 1 micron and $100 \mathrm{~nm}$ glass channels. Electrophoresis 35(2-3):412-418

181. Menard LD, Ramsey JM (2012) Electrokinetically-driven transport of DNA through focused ion beam milled nanofluidic channels. Anal Chem 85(2):1146-1153

182. Castillo-Fernandez O, Salieb-Beugelaar GB, van Nieuwkasteele JW, Bomer JG, Arundell M, Samitier J, van den Berg A, Eijkel JCT (2011) Electrokinetic DNA transport in $20 \mathrm{~nm}$-high nanoslits: evidence for movement through a wall-adsorbed polymer nanogel. Electrophoresis 32(18):2402-2409

183. Cao Z, Yobas L (2013) Fast DNA sieving through submicrometer cylindrical glass capillary matrix. Anal Chem 86(1):737-743

184. Nazemifard N, Wang L, Ye W, Bhattacharjee S, Masliyah JH, Harrison DJ (2012) A systematic evaluation of the role of crystalline order in nanoporous materials on DNA separation. Lab Chip 12(1):146-152 